\title{
ATP-Bioluminescence as a method to evaluated microbiological quality of UHT milk
}

\author{
[ATP-Bioluminescência como método para avaliação da qualidade \\ microbiológica de leite UAT] \\ A.F. Cunha ${ }^{1}$, A.D. Lage $^{1}$, M.M. Pereira e Araújo ${ }^{1}$, C.F. Abreu ${ }^{2}$, A.R. Tassinari ${ }^{2}$, \\ M.A. Ferraz ${ }^{2}$, K. Davenport ${ }^{3}$, M.M.O.P. Cerqueira ${ }^{1}$ \\ ${ }^{1}$ Escola de Veterinária - Universidade Federal de Minas Gerais - Belo Horizonte, MG, Brasil \\ ${ }^{2} 3 \mathrm{M}$ Brazil - Sumaré, SP, Brasil \\ ${ }^{3} 3 \mathrm{M}$ United States - St. Paul, MN, United States
}

\begin{abstract}
New approaches are needed to quickly indicate possible contamination of UHT milk, among them the technique of ATP-Bioluminescence. Therefore, the aim of this study was to compare the results of culture methods with the results of ATP-Bioluminescence technique of 102 UHT whole milk samples incubated at 48, 72, and 168 hours. UHT milk samples were analyzed for the presence of mesophilic and psychrotrophic aerobic microorganisms using Plate Count Agar (PCA), Brain-Heart Infusion (BHI) media and Petrifilm ${ }^{\mathrm{TM}}$ Aerobic Count (AC) plates. The ATP-Bioluminescence technique was applied through the Microbial Luminescent Screening (MLS) system. Significant correlations were found between counts of aerobic mesophilic microorganisms on PCA, Petrifilm ${ }^{\mathrm{TM}} \mathrm{AC}, \mathrm{BHI}$ and results of ATP bioluminescence technique $(\mathrm{P} \leq 0.05)$. The ATP-Bioluminescence technique had higher correlation with counting method in PCA than BHI media. At lower pass/fail limits of Relative Light Units (60, 50, 45 and $40 \mathrm{RLU})$, the number of samples identified as positive increased and statistically agreed with aerobic mesophilic microorganism counts $(\mathrm{P}>0.05)$. For the dairy industry, the ATP-Bioluminescence technique may become an important tool that assists the official methods to quickly monitor the microbiological quality of UHT milk though this will likely require a threshold below 150 RLU.
\end{abstract}

Keywords: ATP-Bioluminescence, microbiology, milk, quality, UHT

\section{RESUMO}

Novos métodos são necessários para detectar de forma rápida a contaminação do leite UAT, entre eles, a técnica de ATP-Bioluminescência. Portanto, objetivou-se comparar os resultados de métodos de cultura tradicionais com os resultados de ATP-Bioluminescência de 102 amostras de leite UAT integral incubadas por 48, 72 e 168 horas. Os leites UAT foram analisados quanto à presença de microorganismos aeróbicos mesófilos e psicrotróficos usando os ágares PCA, BHI e placas Petrifilm ${ }^{T M} A C$. A técnica de ATP-Bioluminescência foi aplicada por meio do sistema Microbial Luminescent Screening $(M L S)$. Significantes correlações foram obtidas entre as contagens de micro-organismos mesófilos aeróbios em PCA, Petrifilm ${ }^{T M}$ AC, BHI e os resultados da técnica de ATP-Bioluminescência (p<0,05). A técnica de ATP-Bioluminescência tem maior correlação com o método de contagem em meio PCA que BHI. Quando valores limites de Unidades Relativas de Luz (60, 50, 45 e 40 RLU) foram menores, o número de amostras identificadas como positivas aumentou e concordou estatisticamente com a contagem de micro-organismos mesófilos aeróbios (P>0,05). Para as indústrias de laticínios, a técnica de ATP-Bioluminescência pode se tornar uma ferramenta auxiliar aos métodos oficiais para o monitoramento rápido da qualidade microbiológica do leite UAT, desde que sejam utilizados limites abaixo de 150 RLU.

Palavras chave: ATP-Bioluminescência, leite, microbiologia, qualidade, UAT

Recebido em 20 de fevereiro de 2014

Aceito em 8 de agosto de 2014

E-mail: adrianofcunha@ hotmail.com.br 


\section{INTRODUCTION}

Despite the growth in the dairy sector in Brazil, the quality of the Ultra High Temperature (UHT) milk commercialized is one of the factors that put a limit on the continued expansion of internal and external markets. After the UHT process, spores of some heat resistant microorganisms and microbes introduced to the milk during packaging can be present in the product, making it legally unfit for use (Simmonds et al., 2003; Rezende-Lago et al., 2007). Moreover, these microorganisms can modify the characteristics of the product, decreasing its shelf-life and potentially compromising the consumer's health (Hassan et al., 2009). For these reasons, the milk quality control tests performed on samples are essential to affirm the safety and quality by the industry itself and by the official inspection sector.

There are many available methodologies for detection and enumeration of microorganisms in milk that can be used for these quality control assays. Some of them are routinely used in laboratories and referenced by research institutions and by the company inspection group. However, these traditional methodologies require extensive amounts of time to obtain the results, making the fast implementation of corrective actions impossible. These methods also require a lot of hands-on time by the technician and may fail in the detection of some important microorganisms that could compromise the product quality. These failures occasionally culminate in important economic losses for the entire milk industry (Park et al., 2001; Vilar et al., 2008; Freitas et al., 2009).

Considering the above, quick methodologies based on ATP-Bioluminescence technique have been developed, but scientific literature about the use of this technique in UHT products is minimal. This technique is based on measuring the microbial ATP concentration found in the sample through a reaction mediated by the enzymatic complex luciferin-luciferase, which has been commercialized in reagent form (Costa et al. 2006). The reaction also requires oxygen and releases light in proportion to the concentration of microbial ATP in the sample. The intensity of the light is measured by a photosensing piece of equipment, called a luminometer (Baker et al., 1992; Griffith et al., 2000; Costa et al., 2006).

These luminometers detect the presence of microbial contamination in milk products by detecting the presence of microbial ATP. While some researchers have attempted to correlate the number of microbes with the amount of light generated by the ATP-Bioluminescence technique, this falsely assumes that the level of this nucleotide by living-microorganism is relatively constant (Griffiths et al., 1993; Finger and Sischo, 2001). However, the high light intensity in a milk sample, shown in Relative Light Units (RLU) is correlated with the high microbial concentration and consequently with high microbial count indicating that this technology is useful to qualitatively determine if the milk sample contains viable microorganisms (Siragusa et al., 1995;; Simm et al., 2008; Luo et al., 2009).

Given the importance of establishing new quality indicators and fast detection methodologies for microorganism in UHT milk, this paper describes the evaluation of UHT milk microbial quality according to Brazilian law using a variety of different culture media and incubation times, and then to compare the culture methods with the ATP-Bioluminescence technique.

\section{MATERIALS AND METHODS}

For the accomplishment of the experiment, 102 UHT whole milk samples were collected randomly across multiple production lots from two large milk companies in the state of Minas Gerais, Brazil, from November (2009) to March (2010). The samples, collected in the original package were quickly transported to the food microbiology laboratory of the veterinary school at the Universidade Federal de Minas Gerais (UFMG), where they were prepared for the tests.

Upon arrival at the laboratory, the UHT milk samples were labeled and incubated at $36 \pm 1^{\circ} \mathrm{C}$ for 48, 72 and 168 hours, with 34 samples for each incubation time. The time of 168 hours was used to fulfill the legal requirements of milk identity and UHT quality (Brazil, 1997). Following the incubation time, the samples were removed from the incubator and submitted to microbiological analyses in duplicate. 
The microbiological analyses were done by the standard plate count method using Plate Count Agar (PCA - Oxoid Ltda., Baingstoke, England) according to Normative Instruction $n^{\circ} 62$ (Brasil, 2003) and in Petrifilm ${ }^{\mathrm{TM}}$ Aerobic Count (Petrifilm $^{\mathrm{TM}}$ AC - 3M Microbiology Products, St. Paul, U.S.A.) plates according to recommendations from the manufacturing company (3M, 2003) for enumeration of aerobic mesophilic $\left(36 \pm 1^{\circ} \mathrm{C} / 48\right.$ hours) and aerobic psychrotrophic $\quad\left(21 \pm 1^{\circ} \mathrm{C} / 25 \quad\right.$ hours $)$ microorganisms according to Marshall (1992). The samples were also analyzed in Brain Heart Infusion broth (BHI - Oxoid Ltda., Baingstoke, England) by the spread plate technique, for enumeration of mesophilic microorganisms $\left(36 \pm 1^{\circ} \mathrm{C} / 48\right.$ hours). $1 \mathrm{~mL}$ of indicative dye, named 2,3,5-Triphenyl Tetrazolium Chloride (TTC $0.5 \% \mathrm{p} / \mathrm{v}$ ) was added to each $100 \mathrm{~mL}$ of PCA and BHI media to facilitate the visualization of the colonies. The results were expressed in Colony Forming Units (CFU)/mL of the product.

The microbial detection analysis by ATPBioluminescence utilized electronic equipment, named the $3 M^{T M}$ Microbial Luminescence System II (MLS - 3M Microbiology Products, St. Paul, U.S.A.), a microplate luminometer with a Universal Serial Bus (USB) computer interface connection commanded by the MLS Software. The test protocols were followed and the handling and the sample preparation were carried in accordance to the manufacturing company (3M, undated).

After the sample analysis, results were expressed in RLU. In accordance to the manufacturer, reading results under $150 \mathrm{RLU}$ indicate that the microbiological quality of the sample is approved. However, in this work, the results were acquired quantitatively in RLU, regardless of the pass/fail limits, for later interpretation.

The results obtained, transformed into $\log$ $(\mathrm{CFU} / \mathrm{mL}+1)$ for the microbial counts and into $\log (\mathrm{RLU}+1)$ for the ATP-Bioluminescence analysis, were analyzed using the Spearman's correlation tests according to Sampaio (2002). Moreover, the results were subjected to McNemar agreement test (Siegel, 1975) for method comparison, considering $100 \mathrm{CFU} / \mathrm{mL}$ as the quality limit for the bacterial counts (Brasil, 1997) and 150 RLU for ATP-Bioluminescence in the MLS. MLS pass/fail limits of 150, 60, 50, 45 and 40 RLU were applied for result interpretation.

\section{RESULTS AND DISCUSSION}

Considering the different methods and incubation times as evaluated by the Spearman test (Table 1), strong and positive correlation was observed $(r \geq 0.70)$, high significance was also observed $(\mathrm{P} \leq 0.05)$ at 48 and 72 hours, when the following assays were compared: Mesophilic microorganisms PCA x MLS, and Mesophilic microorganisms Petrifilm ${ }^{\mathrm{TM}}$ AC $x$ MLS. For the samples incubated for 168 hours, the correlation was significant $(\mathrm{P} \leq 0.05)$, moderate $(0.3 \geq \mathrm{r}<0.7)$, and positive compared to such methods. Therefore, the ATP-Bioluminescence technique that uses the MLS equipment can be a quick and auxiliary method of checking the microbiological quality of the UHT milk, because this technique provides results similar to the standard method (Brazil, 1997).

Table 1. Correlation among the methods used for analyze UHT milk in different incubation times

\begin{tabular}{|c|c|c|c|c|c|c|}
\hline \multirow{2}{*}{ Method comparison } & \multicolumn{2}{|c|}{48 hours } & \multicolumn{2}{|c|}{72 hours } & \multicolumn{2}{|c|}{168 hours } \\
\hline & $\mathrm{p}^{*}$ & $\mathrm{r} * *$ & $\mathrm{p}^{*}$ & $\mathrm{r} * *$ & $\mathrm{p}^{*}$ & $\mathrm{r} * *$ \\
\hline $\begin{array}{l}\text { Mesophilic microorganisms PCA } \\
\text { x MLS }\end{array}$ & 0.0001 & 0.7532 & 0.0001 & 0.7036 & 0.0436 & 0.3978 \\
\hline $\begin{array}{l}\text { Mesophilic microorganisms } \\
\text { Petrifilm }{ }^{\mathrm{TM}} \text { AC x MLS }\end{array}$ & 0.0001 & 0.7517 & 0.0001 & 0.7445 & 0.0023 & 0.4736 \\
\hline $\begin{array}{l}\text { Psychrotrophic microorganisms } \\
\text { PCA x MLS }\end{array}$ & 0.0083 & 0.4081 & 0.0122 & 0.3855 & 0.2910 & 0.0979 \\
\hline $\begin{array}{l}\text { Psychrotrophic microorganisms } \\
\text { Petrifilm }^{\mathrm{TM}} \text { AC x MLS }\end{array}$ & 0.0083 & 0.4081 & 0.0486 & 0.2936 & 0.0589 & 0.0891 \\
\hline $\begin{array}{l}\text { Mesophilic microorganisms BHI } \\
\text { x MLS }\end{array}$ & 0.0028 & 0.4655 & 0.0001 & 0.6039 & 0.1482 & 0.1844 \\
\hline
\end{tabular}

* Values of $\mathrm{P} \leq 0.05$ indicate correlation between the methods by the Spearman test; ${ }^{* *}$ Coefficient of correlation: $\mathrm{r} \geq$ 0.7 indicates strong correlation, $0.3 \geq r<0.7$ indicates moderate correlation, $r<0.3$ indicates weak correlation. 
Some literature (Siragusa et al., 1995; Bell et al., 1996; Costa, 2006; Simm et al., 2008; Luo et al., 2009) demonstrated representative variation of results when comparisons were made between mesophilic standard count and ATPBioluminescence. Other works (Pires et al., 2005; Costa et al., 2006; Vilar et al., 2008) reported techniques involving ATPBioluminescence that measure the ATP regardless of its origin (microbial or not), making the establishment of statistical correlations between the results in RLU and the aerobic mesophilic microorganisms count extremely difficult, since the relation between the microorganism number and the amount of ATP is not constant. Therefore, they concluded that the ATP-Bioluminescence technique could be used only to check the cleanliness conditions of the equipment surface.

MLS is the equipment that detects the presence of microbes in products and uses specific reagents to degrade the somatic and free ATP and then extracts the microbial ATP for measurement by the bioluminescence reaction. Evaluating samples of UHT milk drink and UHT milk cream, Cunha et al. (2013) demonstrated high specificity of this system, which was able to detect samples with low counts of aerobic microorganisms. Therefore, it was expected that the MLS results would be similar to the counts in plate (BHI and PCA media and Petrifilm ${ }^{\mathrm{TM}}$ AC) in UHT milk samples. This, in fact, is what was observed except for the counts in BHI incubated for 168 hours.

Using BHI media, Montanari et al. (2004) reported that such media allows the recovery of small, visible forming colony units (CFU) from samples of thermal-treated milk while these samples do not produce colonies in modified PCA media. The authors concluded that the PCA media is not ideal for enumeration of sporulating bacteria as B. sporothermodurans that caused false negative results on the PCA. Petterson et al. (1996) also noticed that B. sporothermodurans grows more efficiently in BHI media.

In this work it was expected that the results in MLS would present stronger correlations with the counts of mesophilic microorganisms in BHI media relative to PCA media since the MLS system detects all the bacterial cells, including some species of Bacillus gender. However, although the counts of aerobic mesophilic in BHI media and the results in MLS presented some correlations $(\mathrm{P} \leq 0.05)$ in the incubation times of 48 and 72 hours, these were weaker $(0.3 \geq \mathrm{r}<$ $0.7)$ if compared to the correlations between the counts of mesophilic microorganisms in PCA media and the results in MLS, or, in the case of the 168 hour incubation, not even significant $(\mathrm{P}>0.05)$. This can be attributed to the negative detection or low counts on BHI media.

Moderate $(0.3 \geq \mathrm{r}<0.7)$, positive and significant $(\mathrm{P} \leq 0.05)$ correlation were noticed among the counts of psychrotrophic microorganisms in PCA media and the results in MLS (48 and 72 $\mathrm{h}$ ); and counts of psychrotrophic in Petrifilm ${ }^{\mathrm{TM}}$ $\mathrm{AC}$ and results in MLS (48 and $72 \mathrm{~h}$ ). When the samples were incubated at 168 hours the correlation was not significant $(\mathrm{P} \leq 0.05)$ compared to such methods. The MLS equipment counts all the microorganisms by its microbial ATP and the counts of psychrotrophic microorganisms in the analyzed samples were low or absent, strong correlations between the two methods were not observed. Although the count of psychrotrophic in Petrifilm ${ }^{\mathrm{TM}} \mathrm{AC}$ is officially accepted (Werhr and Frank, 2004), studies demonstrate that this count did not have a good correlation with the psychrotrophic count by the official method using PCA medium (Tavolaro et al., 2005; Senyk et al., 1987).

Table 2 shows the agreements among the plate count methods with a reference level of 100 $\mathrm{CFU} / \mathrm{mL}$ and the MLS system using different pass/fail limits $150,60,50,45$, and 40 RLU). In 48 hours of incubation, agreement was noticed $(\mathrm{P}>0.05)$ when the counts in PCA and BHI media were compared with the results given by the ATP-Bioluminescence method made in MLS system. Agreements between the counts of mesophilic microorganisms in Petrifilm ${ }^{\mathrm{TM}} \mathrm{AC}$ plate and the counts in MLS occurred only under the limit of $60 \mathrm{RLU}(\mathrm{P}>0.05)$.

With 72 hours of UHT milk incubation (Table 3 ), and using the MLS pass/fail value of 150 RLU, there was agreement $(\mathrm{P}>0.05)$ only when the counts in BHI media and the results of ATPBioluminescence in MLS system were compared. The agreements among the counts of mesophilic microorganisms in PCA media and in Petrifilm $^{\mathrm{TM}} \mathrm{AC}$ plates and the counts in MLS occurred only in limits under 50 RLU ( $P>0.05)$. 
Table 2. Agreement among the methods used for analyze UHT milk incubated during 48 hours (for different limits of RLU)

\begin{tabular}{|c|c|c|c|c|c|}
\hline \multirow{2}{*}{ Methods comparison } & \multicolumn{5}{|c|}{48 hours (p-value $*)$} \\
\hline & 150 RLU & 60 RLU & 50 RLU & 45 RLU & 40 RLU \\
\hline $\begin{array}{l}\text { Mesophilic microorganisms } \\
\text { PCA }^{* *} \times \text { MLS }\end{array}$ & 0.1250 & 1.0000 & 1.0000 & 1.0000 & 1.0000 \\
\hline $\begin{array}{l}\text { Mesophilic microorganisms } \\
\text { Petrifilm }{ }^{\mathrm{TM}} \mathrm{AC}^{* *} \times \text { MLS }\end{array}$ & 0.0215 & 0.2190 & 0.3750 & 0.3750 & 0.3750 \\
\hline $\begin{array}{l}\text { Psychrotrophic microorganisms } \\
\text { PCA }^{* *} \times \text { MLS }\end{array}$ & 0.5000 & 0.0313 & 0.0156 & 0.0156 & 0.0156 \\
\hline $\begin{array}{l}\text { Psychrotrophic microorganisms } \\
\text { Petrifilm }^{\mathrm{TM}} \mathrm{AC}^{* *} \times \text { MLS }\end{array}$ & 0.5000 & 0.0313 & 0.0156 & 0.0156 & 0.0156 \\
\hline $\begin{array}{l}\text { Mesophilic microorganisms } \\
\text { BHI }^{* *} \text { x MLS }\end{array}$ & 0.5000 & 0.6250 & 0.2500 & 0.2500 & 0.2500 \\
\hline
\end{tabular}

Table 3. Agreement among the methods used for analyze UHT milk incubated during 72 hours (for different limits of RLU)

\begin{tabular}{|c|c|c|c|c|c|}
\hline \multirow{2}{*}{ Methods comparison } & \multicolumn{5}{|c|}{72 hours (p-value*) } \\
\hline & $150 \mathrm{RLU}$ & 60 RLU & 50 RLU & $45 \mathrm{RLU}$ & $40 \mathrm{RLU}$ \\
\hline $\begin{array}{l}\text { Mesophilic microorganisms PCA } \\
\text { x MLS }\end{array}$ & 0.0156 & 0.0313 & 0.1250 & 0.2500 & 0.2500 \\
\hline $\begin{array}{l}\text { Mesophilic microorganisms } \\
\text { Petrifilm }{ }^{\mathrm{TM}} \mathrm{AC}^{* * *} \times \text { MLS }\end{array}$ & 0.0156 & 0.0313 & 0.1250 & 0.2500 & 0.2500 \\
\hline $\begin{array}{l}\text { Psychrotrophic microorganisms } \\
\text { PCA }^{* *} \times \text { MLS }\end{array}$ & 0.5000 & 0.2500 & 0.0625 & 0.0313 & 0.0313 \\
\hline $\begin{array}{l}\text { Psychrotrophic microorganisms } \\
\text { Petrifilm }{ }^{\mathrm{TM}} \mathrm{AC}^{* *} \mathrm{x} \text { MLS }\end{array}$ & 0.5000 & 0.2500 & 0.0625 & 0.0313 & 0.0313 \\
\hline $\begin{array}{l}\text { Mesophilic microorganisms BHI } \\
\text { x MLS }\end{array}$ & 0.1250 & 0.2500 & 1.0000 & 1.0000 & 1.0000 \\
\hline
\end{tabular}

With 168 hours of UHT milk incubation (Table 4), the agreement among the methodologies varied according to the RLU pass/fail value. For aerobic mesophilic microorganisms in PCA and BHI media and the results in MLS, agreement $(\mathrm{P}>0.05)$ was observed with the limit of 60 RLU. For the aerobic mesophilic microorganism's count in Petrifilm ${ }^{\mathrm{TM}}$ AC plate, the agreement with the MLS was noticed with a value of 50 RLU. This demonstrates that, in this incubation time, as well as in the time of 48 hours, the type of method used for aerobic mesophilic microorganism's count can present different results when compared to ATP-Bioluminescence values in MLS.

It is possible to observe that as the RLU limit is reduced, there is better agreement $(\mathrm{P}>0.05)$ among different evaluated methodologies and MLS, except for the counts of psychrotrophic microorganisms in PCA media and in Petrifilm ${ }^{\mathrm{TM}}$ AC plate $(\mathrm{P} \leq 0.05)$. Such observation demonstrates the importance of values under the 150 RLU reference limit in the ATPBioluminescence technique performed by the MLS equipment in order to obtain agreement between the counts of mesophilic microorganisms in PCA, BHI media, or Petrifilm $^{\mathrm{TM}}$ AC plates and the MLS system.

The agreement observed among the results in MLS system and the counts of psychrotrophic microorganisms in PCA media and in Petrifilm $^{\mathrm{TM}}$ AC plate, when the limit of 150 RLU ( $P>0.05)$ was considered, can be attributed to the absence of samples above this limit when using the respective techniques. As the RLU limit decreases, there are some disagreements among the methods, because samples considered negative when using the limit of $150 \mathrm{RLU}$ are no longer considered negative when limits under 60 RLU are used. 
Table 4. Agreement among the methods used for analyze UHT milk incubated during 168 hours (for different limits of RLU)

\begin{tabular}{|c|c|c|c|c|c|}
\hline \multirow{2}{*}{ Methods comparison } & \multicolumn{5}{|c|}{168 hours (p-value*) } \\
\hline & $150 \mathrm{RLU}$ & $60 \mathrm{RLU}$ & $50 \mathrm{RLU}$ & $45 \mathrm{RLU}$ & $40 \mathrm{RLU}$ \\
\hline $\begin{array}{l}\text { Mesophilic microorganisms } \\
\text { PCA }^{* *} \times \text { MLS }\end{array}$ & 0.0039 & 0.1800 & 0.7270 & 0.7270 & 0.7270 \\
\hline $\begin{array}{l}\text { Mesophilic microorganisms } \\
\text { Petrifilm }{ }^{\mathrm{TM}} \mathrm{AC}^{* *} \times \text { MLS }\end{array}$ & 0.0009 & 0.0391 & 0.2890 & 0.2890 & 0.2890 \\
\hline $\begin{array}{l}\text { Psychrotrophic microorganisms } \\
\text { PCA }^{* *} \times \text { MLS }\end{array}$ & 1.0000 & 0.1250 & 0.0156 & 0.0156 & 0.0156 \\
\hline $\begin{array}{l}\text { Psychrotrophic microorganisms } \\
\text { Petrifilm }^{\mathrm{TM}} \mathrm{AC}^{* *} \times \text { MLS }\end{array}$ & 1.0000 & 0.1250 & 0.0156 & 0.0156 & 0.0156 \\
\hline $\begin{array}{l}\text { Mesophilic microorganisms } \\
\text { BHI }^{* *} \times \text { MLS }\end{array}$ & 0.0039 & 0.1800 & 0.7270 & 0.7270 & 0.7270 \\
\hline
\end{tabular}

* Values of $\mathrm{P}>0.05$ indicate agreement among the methods by the McNemar test; ** Reference value about 100 $\mathrm{CFU} / \mathrm{mL}$ in accordance to Brasil (1997).

Dairy industries could have economic gains due to the fast liberation of the UHT milk lots for commercialization with a reduction time of two days since the incubation time required for the plates or Petrifilm ${ }^{\mathrm{TM}}$ (48 hours) would be eliminated. Such advantage would allow quicker corrective actions when high levels of contamination in the UHT milk are detected. However, the official methods cannot be substituted by the ATP-Bioluminescence performed by the MLS system. This should only be used as an auxiliary method for quick release of UHT milk to the industry.

In practical terms, the ATP quantification made by the ATP-Bioluminescence technique showed its worthy because of the low time required (40 minutes for each 96 samples) for performing the tests. The stability of the reagents (ATPase, extractant and L/L1) used for the equipment verification is really necessary to guarantee the analytical results. For this reason, before the analysis of UHT samples can be performed, it is essential that the equipment and reagents be evaluated using the reagent control assay as a standard procedure.

The previous preparation of glassware and culture media, necessary for the standard methodologies, is not necessary when MLS equipment is used. The results were easily obtained and interpreted due to the automation of the method. The convenience, quickness and easiness of using this equipment must justify the initial investment. Moreover, the costs with reagents, ATP-control and micro wells that are consumed daily must be compared with the costs related to the use of conventional methodologies.

\section{CONCLUSIONS}

The counts of aerobic mesophilic microorganisms in PCA and BHI media and in Petrifilm $^{\text {TM }}$ AC plates had good qualitative correlation with the results of the ATPBioluminescence technique done with the MLS system. The standard counting method in plates had higher correlation with the ATPBioluminescence technique than the BHI media.

The ATP-Bioluminescence method performed by the MLS system can be used by the milk industries as a new and auxiliary tool for quickly testing the UHT milk quality. However, it is necessary to review the MLS RLU limit for the UHT milk analysis. The data in this work strongly suggests the need for a pass/fail value under 150 RLU.

\section{REFERENCES}

3M. Microbial Luminescence System (MLS). 3M from Brazil Ltda. Instructions Manual, USA. $88 \mathrm{p}$.

3M. 3M ${ }^{\mathrm{TM}}$ Petrifilm ${ }^{\mathrm{TM}}$ Aerobic Count Plates. 3M from Brazil Ltda. Instructions Manual, USA, 2003. 82p.

BAKER, J.M.; GRIFFITHS, M.W.; COLLINSTHOMPSON, D.L. Bacterial bioluminescence: applications in food microbiology. J. of Food Protec., v.55, p.62-70, 1992. 
BELL, C.; BOWLE, C.D.; TOSZEGHY, M.J.K.; NEAVES, P. Development of a hygiene standard for raw milk based on the Lumac ATPbioluminescence method. Internat. Dairy J., v.6, p.709-713, 1996.

BRASIL, Ministério da Agricultura. Pecuária e Abastecimento. Portaria No 370 de 4 de setembro de 1997. Regulamento Técnico de Identidade e Qualidade do leite UAT (UHT). Diário Oficial da União, Brasília, 4 de setembro de 1997.

BRASIL, Ministério da Agricultura. Pecuária e Abastecimento. Instrução Normativa $N^{\circ} 62$ de 26 de agosto de 2003. Métodos analíticos oficiais para análises microbiológicas para controle de produtos de origem animal e água. Diário Oficial da União, Brasília, 18 de setembro de 2003.

COSTA, P.D.; ANDRADE, N.J.; BRANDÃO, S.C.C. et al. ATP-bioluminescence assay as an alternative for hygiene-monitoring procedures of stainless steel milk contact surfaces. Braz. J. Microbiol., v.37, p.345-349, 2006.

CUNHA, A.F.; LAGE, A.D.; PEREIRA E ARAÚJO, M.M. et al. Avaliação da qualidade microbiológica de bebida láctea e creme de leite UAT por ATP-Bioluminescência. Arq. Bras. Med. Vet. Zootec., v.65, p.595-600, 2013.

FINGER, R.; SISCHO, W.M. Bioluminescence as a technique to evaluate udder preparation. $J$. Dairy Sci., v.84, p.818-823, 2001.

FREITAS, R.; NERO, L.A.; CARVALHO, A.F. Enumeration of mesophilic aerobes in milk: evaluation of standard official protocols and Petrifilm aerobic count plates. J. Dairy Sci., v.92, p.3069-3073, 2009.

GRIFFITH, C.J.; COOPER, R.A.; GILMORE, J. et al. An evaluation of hospital cleaning regimes and standards. J. Hospital Infect., v.45, p.19-28, 2000 .

GRIFFITHS, M.W. Applications of bioluminescence in the dairy industry. J. Dairy Sci., v.76, p.3118-3125, 1993.

HASSAN, N.B.A.; ABDALLA, M.O.M.; NOUR, A.A.A.M. Microbiological quality of heat-trated milk during storage. Pakistan $J$. Nutrit., v.8, p.1845-1848, 2009.

LUO, J.; LIU, X.; TIAN, Q. et al. Disposable bioluminescence based biosensor for detection of bacterial count in food. Analytical Biochem., v.394, p.1-6, 2009.
MARSHALL, R.T. Standard methods for the examination of dairy products. $16^{\text {th }} \mathrm{Ed}$. Washington: American Public Health Association, Washington, 1992.

MONTANARI, G.; BORSARI, A.; CHIAVARI, C. et al. Morphological and phenotypical characterization of Bacillus sporothermodurans. J. Appl. Microbiol., v.97, p.802-809, 2004.

PARK, Y.H.; SEO, K.S.; AHN, J.S. et al. Evaluation of the Petrifilm ${ }^{\mathrm{TM}}$ Plate method for the enumeration of aerobic microorganisms and coliforms in retailed meat samples. J. Food Protect., v.64, p.1841-1843, 2001.

PETTERSON, B.; LEMBKE, F.; HAMMER, P. et al. Bacillus sporothermodurans, a new species producing highly heat-resitent endospores. International J. Systematic Bacteriol., v.46, p.756-764, 1996.

PIRES, A.C.S.; ARAÚJO, E.A.; CAMILLOTO, G.P. et al. Condições higiênicas de fatiadores de frios avaliadas por ATP-bioluminescência e contagem microbiana: sugestão de higienização conforme RDC 275 da ANVISA. Alimentos $e$ Nutrição, v.16, p.123-129, 2005.

REZENDE-LAGO, N.C.M.; ROSSI, J.R. O.D.; VIDAL-MARTINS, A.M.C.; AMARAL, L.A. Ocorrência de Bacillus cereus em leite integral e capacidade enterotoxigênica das cepas isoladas. Arq. Bras. Med. Vet. Zootec., v.59, p.1563-1569, 2007.

SAMPAIO, I.B.M. Estatística aplicada a experimentação animal. 2.ed. Belo Horizonte: Fundação de Ensino e Pesquisa em Medicina Veterinária e Zootecnia, 2002. 265p.

SENYK, G.F.; KOZLOWSKI, S.M.; NOAR, P.S. et al. Comparison of dry culture medium and conventional plating techniques for enumeration of bacteria in pasteurized fluid milk. J. Dairy Sci., v.70, p.1152-1158, 1987.

SIEGEL, S. Estatística não-paramétrica para as ciências do comportamento. São Paulo: McGraw-Hill do Brasil, 1975. 350p.

SIMM, E.M.; ANDRADE, N.J.; MENDONÇA, R.C.S. et al. Interference of some organic substances and microorganisms adhered to stainless steel in ATP-bioluminescence measurement. Braz. Arch. Biol. Technol., v.51, p.587-593, 2008. 


\section{Cunha et al.}

SIMMONDS, P.; MOSSEL, B.L.; INTARAPHAN, T.; DEETH, H.C. Heat resistance of Bacillus spores when adhered to stainless steel and its relationship to spore hydrophobicity. J. Food Protect., v.66, p.2070-2075, 2003.

SIRAGUSA，G.R.; CUTTER，C.N.; DORSA, W.J.; KOOHMARAIE, M. Use of rapid microbial ATP bioluminescence assay to detect contamination on beef and pork carcasses. $J$. Food Protection, v.58; p.770-775, 1995.

TAVOLARO, P.; FERRATI, A.R.; DESTRO, M.T. et al. Performance of two ready-to-use systems for enumeration of aerobic mesophilic microorganisms in frozen goat milk. Braz. J. Microbiol., v.36, p.295-300, 2005.
VILAR, M.J.; RODRÍGUEZ-OTERO, J.L.; DIÉGUEZ, F.J. et al. Application of ATP bioluminescence for evaluation of surface cleanliness of milking equipment. Inter. J. Food Microbiol., v.125, p.357-361, 2008.

WERHR, H.H.; FRANK, J.F. Microbiological count methods. In: Standard Methods for the examination of dairy products. 17.ed. Washington: American Public Health Association, 2004. p.153-186. 